\title{
High-temperature gold-copper extraction with chloride flux in lava tubes of Tolbachik volcano (Kamchatka)
}

\author{
Vadim S. Kamenetsky ${ }^{1,2,3}$ (D) | Alexander Belousov ${ }^{3}$ | Victor V.Sharygin ${ }^{4,5}$ | Liudmila \\ M. Zhitova ${ }^{4,5}$ | Kathy Ehrig ${ }^{6}$ | Michael E. Zelenski ${ }^{1}$ | llya Chaplygin ${ }^{7}$ | Marina \\ A. Yudovskaya ${ }^{7}$ | Pavel N. Nesterenko ${ }^{8}$ | Sergey M. Zakharov ${ }^{5}$
}

${ }^{1}$ Institute of Experimental Mineralogy, Chernogolovka, Russia

${ }^{2}$ University of Tasmania, Hobart, TAS, Australia

${ }^{3}$ Institute of Volcanology and Seismology, Petropavlovsk-Kamchatsky, Russia

${ }^{4}$ V.S. Sobolev Institute of Geology and Mineralogy, Novosibirsk, Russia

${ }^{5}$ Novosibirsk State University, Novosibirsk, Russia

${ }^{6}$ BHP Olympic Dam, Adelaide, SA, Australia ${ }^{7}$ Institute of Geology of Ore Deposits, Petrography, Mineralogy and Geochemistry, Moscow, Russia

${ }^{8}$ M.V. Lomonosov Moscow State University, Moscow, Russia

\section{Correspondence}

Vadim S. Kamenetsky, University of Tasmania, Hobart, TAS, Australia.

Email: Dima.Kamenetsky@utas.edu.au

Funding information

Russian Science Foundation, Grant/Award Number: 16-17-10145

\begin{abstract}
Subvolcanic environments in supra-subduction zones are renowned for hosting epithermal deposits that often contain electrum and native gold, including bonanza examples. This study examined mineral assemblages and processes occurring in shallow-crust volcanic settings using recent eruption (2012-2013) of the basaltic Tolbachik volcano in the Kamchatka arc. The Tolbachik eruptive system is characterized by an extensive system of lava tubes. After cessation of magma input, the tubes maintained the flow of hot oxidized gases that episodically interacted with the lava surfaces and sulphate-chloride precipitates from volcanic gases on these surfaces. The gas-rock interaction had strong pyrometamorphic effects that resulted in the formation of molten salt, oxidized (tenorite, hematite, Cu-rich magnesioferrite) and skarn-like silicate mineral assemblages. By analogy with experimental studies, we propose that a combination of these processes was responsible for extraction of metals from the basaltic wall rocks and deposition of $\mathrm{Cu}$-, $\mathrm{Fe}$ - and $\mathrm{Cu}$-Fe-oxides and native gold.
\end{abstract}

\section{1 | INTRODUCTION}

Metal transport to the crust in mantle-derived magmas erupted at convergent plate boundaries can be associated with ore formation in hypabyssal intrusions and shallow subvolcanic environments, known respectively as "porphyry" and "epithermal" deposits of copper, gold and silver (e.g. Cooke, Hollings, \& Walshe, 2005; Cooke \& Simmons, 2000; Henley \& Berger, 2013; Sillitoe, 1993, 2010; Taylor, 2007). The relevant genetic models consider a supply of heat, volatiles and ore-forming components directly to hydrothermal fluids that stream into suitable conduits within solidifying magmas and country rocks (e.g. Burnham, 1998; Cline \& Bodnar, 1991; Hedenquist \& Lowenstern, 1994). In the case of epithermal bonanza gold deposits in the upper parts of volcanic centres exceptionally gold-rich fluids (Sillitoe, 1993), colloidal silica-gold suspensions (Herrington \& Wilkinson, 1993; Saunders, 1990, 1994; Saunders \& Schoenly, 1995; Hannington, Hardardóttir, Garbe-Schönberg, \& Brown, 2016) and efficient mechanisms of gold precipitation have been proposed. Transport of gold in magmatic $\mathrm{HCl}-\mathrm{H}_{2} \mathrm{~S}-\mathrm{H}_{2} \mathrm{O}$ gas mixtures (e.g. Hurtig \& Williams-Jones, 2015; Williams-Jones, Bowell, \& Migdisov, 2009; Williams-Jones $\&$ Heinrich, 2005 and references therein) has been advocated for unique occurrences of native gold in aerosols of Erebus, Antarctica (Meeker, Chuan, Kyle, \& Palais, 1991) and among fumarolic mineralization in the uppermost parts of some active volcanic systems, such as Vulcano, Aeolian arc (Fulignati \& Sbrana, 1998), Colima, Mexico (Taran, Bernard, Gavilanes, \& Africano, 2000), Kudryavy, Kurile island arc (Yudovskaya et al., 2006) and Tolbachik, 
Kamchatka arc (Chaplygin, Yudovskaya, Vergasova, \& Mokhov, 2015; Serafimova, Kazmin, \& Dobroskok, 2001; Vergasova et al., 2001; Zelenski, Kamenetsky, \& Hedenquist, 2016).

Tolbachik volcano is renowned for diverse manifestations of native gold occurrences, formed during fissure eruptions in 1975-1976 and 2012-2013. Abundant aggregates and euhedral crystals of native gold, including exceptional bonanza samples with up to $2.8 \mathrm{~kg} / \mathrm{t}$ (Serafimova et al., 2001) are present with copper minerals in some fumarolic incrustations (Chaplygin et al., 2015; Vergasova et al., 2001; Zelenski et al., 2016). In addition to conventional modelling of the Tolbachik gold precipitation from the oxidized volcanic gas (Chaplygin et al., 2015), the transport of gold in a molten state was suggested for gold splatters (Zelenski et al., 2016). Furthermore, recycling of epithermal gold-bearing veins in volcanic-sedimentary rocks beneath the volcano has been advocated for $\leq 1 \mathrm{~mm}$ electrum nuggets in the 1975 Tolbachik lava and lapilli (Zelenski et al., 2016); however, it still remains unclear where and how gold is sourced.

As the underground ore-forming systems are inaccessible, our study examines processes and mineral assemblages in the cooling lava tubes formed during 2012-2013 Tolbachik eruption of the volcano (Kamchatka arc). We propose that a molten chloride salt combined with oxidized volcanic gases is very efficient in extracting and transporting metals in volcanic systems. The salt-rich media has a potential to create, recycle and upgrade metal accumulations in the shallow crust, ultimately contributing to a gold bonanza near the surface.

\section{2 | LAVA TUBES DURING THE 2012-2013 TOLBACHIK ERUPTION}

The 2012-2013 flank fissure eruption of the Tolbachik volcano in Kamchatka Peninsula (Far East, Russia) lasted 9 months and produced $0.54 \mathrm{~km}^{3}$ of basaltic trachyandesite lava that covered the total area of $36 \mathrm{~km}^{2}$ with maximum thickness of $70 \mathrm{~m}$ (Belousov, Belousova, Edwards, Volynets, \& Melnikov, 2015) (Figure S1). When the rate of magma discharge declined from the initial $440 \mathrm{~m}^{3} / \mathrm{s}$ to several tens of $\mathrm{m}^{3} / \mathrm{s}$ in January 2013 , lava tubes started forming by surface solidification ("roofing") of the open lava channels (Figure 1a, Figure S2). Later on during the eruption the tube system extended downslope by complex branching to reach a total length of $\sim 4 \mathrm{~km}$ and included multiple interlacing tubes with average diameters between 1 and $10 \mathrm{~m}$.

Lava flowing through the tube system preserved temperature and viscosity close to those in the magma source $\left(1,082^{\circ} \mathrm{C}\right.$ and $(1-$ 3) $\times 10^{3} \mathrm{~Pa}$ s; Belousov \& Belousova, 2018), but experienced notable degassing, frequently visible as bursting bubbles at the lava surface. Gases released from the lava leaked upward through the fractured roof of the tubes as well as vigorously vented out through "skylights." The temperature of venting gases, measured directly at the skylights (Chaplygin et al., 2016; Zelenski, Malik, \& Taran, 2014; Figure S3), was nearly similar to the temperature of the lava $\left(<1,065^{\circ} \mathrm{C}\right)$. Rocks in the areas of gas venting (skylights and open cracks) were covered
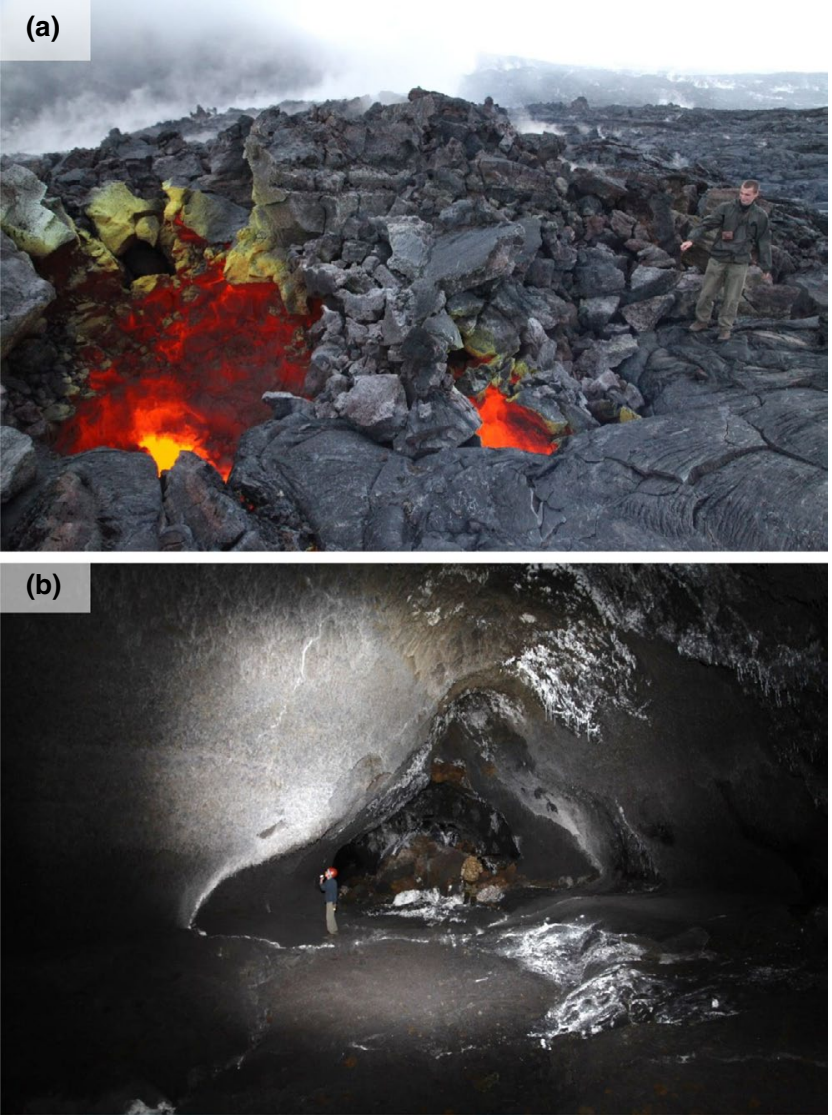

FIGURE 1 Lava tubes during (a) and after (b) the Tolbachik eruption in 2012-2013. (a) Glowing skylights in the roof of the lava tube, emitting a mixture of volcanic gas and hot air, and surrounded by colourful fumarolic incrustations; (b) Walls and roof of the "Duplex" lava tube segment near the entrance covered by white chlorides in June 2018 [Colour figure can be viewed at wileyonlinelibrary.com]

by colourful crusts composed of various minerals emplaced from the venting gas (Figure 1a, Figures S2 and S3).

\section{LAVA TUBES AFTER THE ERUPTION}

Towards eruption cessation, the tube system became separated by plugs of solidified lava into numerous isolated segments that started to cool from $\sim 1,000^{\circ} \mathrm{C}$ independently from each other. Segments with intensive air inflow through their entrances cooled down to ambient temperatures within a year, whereas segments with gas outflow still had elevated temperatures in 2017. For example, one segment called "Sushilka" (means "Dryer") cooled to $20^{\circ} \mathrm{C}$ by mid-2015, then the temperature abruptly increased to $100-150^{\circ} \mathrm{C}$ and remained at this level (last measurement in August 2017), because the air circulation reversed back from gas inflow to gas outflow.

The studied tube "Dvoinaya" (means "Duplex"), represented by two galleries located one above the other), is a 150-m long segment of the lava tube system that was cut-off from lava supply in May 2013. Since then the tube (that originally had gas outflow from its 
entrance) started to cool and became accessible in 2017 (Figure 1b, Figures S4 and S5). We recorded very complex distribution of temperatures in the upper gallery: $\sim 50^{\circ} \mathrm{C}$ in the entrance area, while the walls inside the tube had strong temperature gradients from $100^{\circ} \mathrm{C}$ to up to $540^{\circ} \mathrm{C}$ in some wall fractures (Figure S5b). Entrance to the lower inaccessible gallery of this tube segment had air temperature around $200^{\circ} \mathrm{C}$. Noteworthy, at the same time the incandescent cracks at the surface of the lava field $100 \mathrm{~m}$ from the tube entrance were as hot as $660^{\circ} \mathrm{C}$

\section{4 | MINERAL ASSEMBLAGES IN LAVA} TUBES

Various, dominantly Na-, K- and Cu-bearing chloride and sulphate minerals (Chaplygin et al., 2015; Vergasova \& Filatov, 2012) are present at the surface as colourful incrustations around incandescent gas-venting skylights and cracks in lava (Figure 1a, Figures S2 and S3). In contrast, the interior of the recently cooled parts of lava tubes, especially around wall fractures, is coated by finegrained, greyish-white material. The mineral assemblage, covering the vesicular lava in the "Duplex" cave (Figures $1 \mathrm{~b}$ and 2, Figures S4, S6, S7), was studied using scanning electron microscopy and electron microprobe analyser (see Methods in Data S1 and Sharygin, Kamenetsky, Zhitova, Belousov, \& Abersteiner, 2018 for more details). The main minerals on the rock surfaces and within the vesicles are $\mathrm{Na}-\mathrm{K}$ chlorides, represented by halite and sylvite in roughly equal proportions (Figure 2a-c) and tenorite (CuO). Sylvite forms the majority of cubic crystals that are sprinkled with round and rod- and lens-shaped halite with different sizes and orientation (Figure $2 \mathrm{c}$ ). The overall vermicular texture of chlorides is reminiscent of immiscibility, most likely in the form
FIGURE 2 Optical photographs (a, b) and backscattered electron images (c-f) showing mineral assemblage on the lava walls in the "Duplex" lava tube segment. The main minerals are halite (Ha), sylvite (Sy), tenorite (Tn), hematite (Hem), Cu-bearing magnesioferrite (MF), high-Ca silicates (e.g. esseneite, melilite-Ess + Mel) and gold (two boxed areas on (e) are shown in detail on Figure $3 a, b)$. Note vermicular textures on (c) represented by halite blebs (dark-grey) in sylvite cubes (light-grey) [Colour figure can be viewed at wileyonlinelibrary.com]
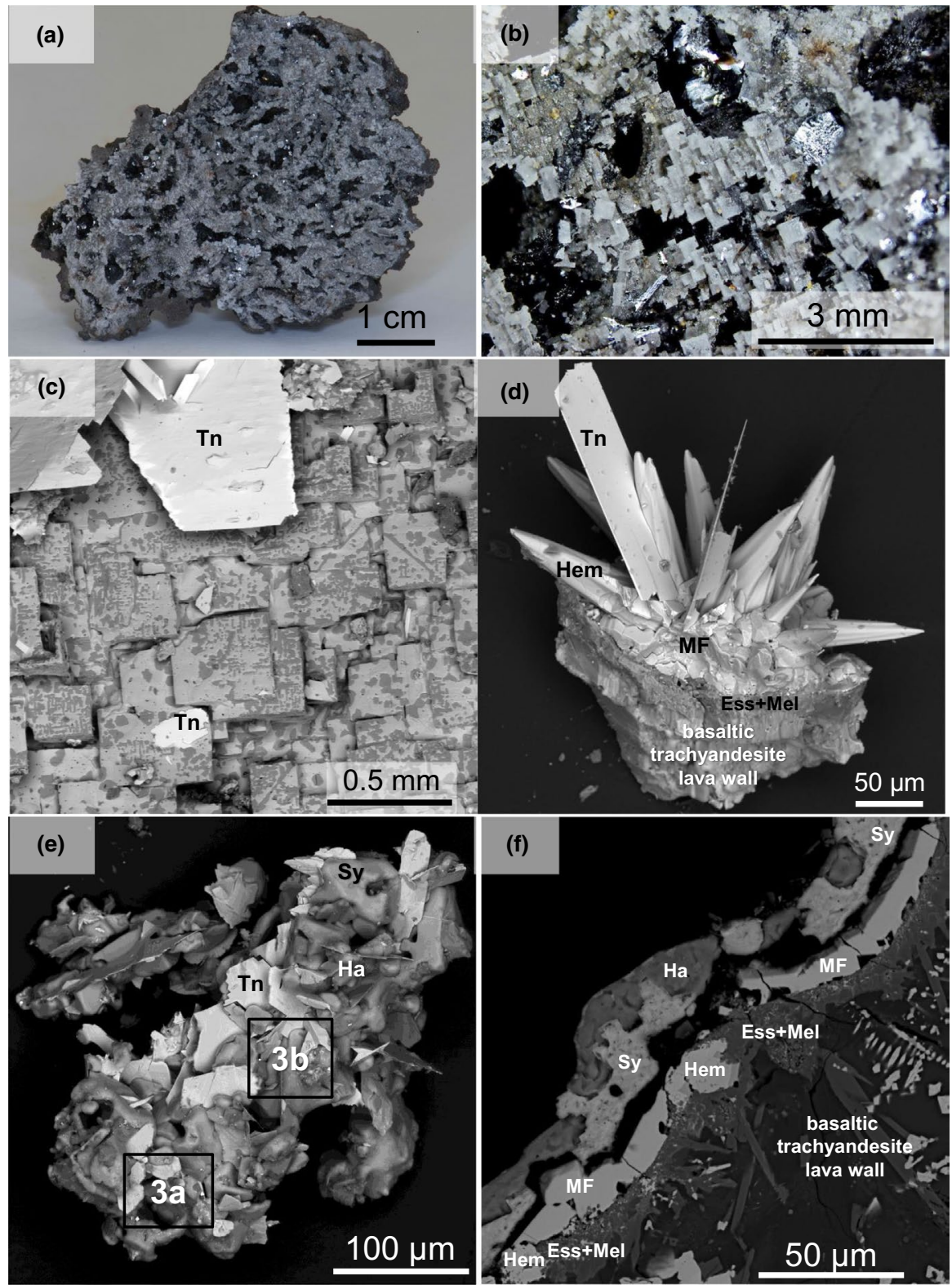
of solid solution breakdown. Platy tenorite is scattered among the chloride masses and crystals and commonly grows into the open space (Figure $2 b-e)$. Small octahedral crystals $(<3 \mu \mathrm{m}$ ) of pure gold are occasionally present among salts (Figures $2 \mathrm{e}$ and $3 \mathrm{a}, \mathrm{b}$ ).

A thin surficial layer $(100 \mu \mathrm{m})$ of the basalt lava is distinctively altered at the contact with the chloride crust (Figure 2f; Figure S6, S7). The outer rim of this reaction zone is represented by octahedral $\mathrm{Cu}$ bearing magnesioferrite $\left((\mathrm{Mg}, \mathrm{Cu})\left(\mathrm{Fe}^{3+}\right)_{2} \mathrm{O}_{4}\right.$ with $5.8-17.3$ wt\% $\mathrm{CuO}$ and up to $0.9 \mathrm{wt} \% \mathrm{TiO}_{2}, 2.4 \mathrm{wt} \% \mathrm{Al}_{2} \mathrm{O}_{3}, 3.0 \mathrm{wt} \% \mathrm{MnO}$ and $0.8 \mathrm{wt} \%$ $\mathrm{ZnO}$ ) that is followed by intergrown hematite and high-Ca silicates inside of the basalt. The high-Ca silicate minerals are represented by esseneite $\left(\mathrm{Ca}_{0.98} \mathrm{Na}_{0.02}\right)\left(\mathrm{Fe}^{3+}{ }_{0.48} \mathrm{Mg}_{0.26} \mathrm{Al}_{0.19} \mathrm{Fe}^{2+}{ }_{0.03} \mathrm{Ti}_{0.03} \mathrm{Mn}_{0.01}\right)$ $\left(\mathrm{Si}_{1.28} \mathrm{Al}_{0.72}\right) \mathrm{O}_{6}, \quad$ Na-melilite/alumoåkermanite $\quad\left(\mathrm{Ca}_{1.40} \mathrm{Na}_{0.59} \mathrm{~K}_{0.01}\right)$ $\left(\mathrm{Al}_{0.85} \mathrm{Mg}_{0.08} \mathrm{Fe}_{0.07}\right)\left(\mathrm{Si}_{1.68} \mathrm{Al}_{0.32}\right) \mathrm{O}_{7}$, wollastonite, monticellite, titanite and grossular garnet. It appears that hematite, magnesioferrite $\mathrm{MgFe}_{2} \mathrm{O}_{4}$ and $\mathrm{Cu}$-rich magnesioferrite can form as a replacement of magmatic oxides in the basalt (magnetite and ilmenite) and by direct crystallization on vesicular walls (see Sharygin et al., 2018 for details).

\section{5 | DISCUSSION}

Gold- and copper-bearing salt crusts covering walls and fractures in the lava tube and associated mineral assemblage of unusual $\mathrm{Cu}$ bearing spinel-supergroup mineral, hematite and high-Ca silicates in the outer rim of the lava substrate may help to decipher processes in the shallow volcanic plumbing system, where magmatic rocks interact with hot oxidized gases.

The recorded $\mathrm{Cu}$-bearing magnesioferrite in a close association with tenorite and hematite (Figure 2f; Figure S6, S7; also see Pekov et al., 2018 for details of Cu-enriched spinel assemblage in fumaroles of the Tolbachik volcano) has analogues in operating base metal smelters worldwide (e.g. Schlesinger, King, Sole, \& Davenport, 2011). For example, the Olympic Dam copper smelter has cuprospinel $\left(\mathrm{CuFe}_{2} \mathrm{O}_{4}\right.$; note "tenorite" $\mathrm{CuO}$ and "hematite" $\mathrm{Fe}_{2} \mathrm{O}_{3}$ components), delafossite $\mathrm{CuFeO}_{2}$, tenorite and Fe-silicates as common products of oxidative melting of copper sulphides, hematite, quartz and K-silicates. Similarly, cuprospinel and other

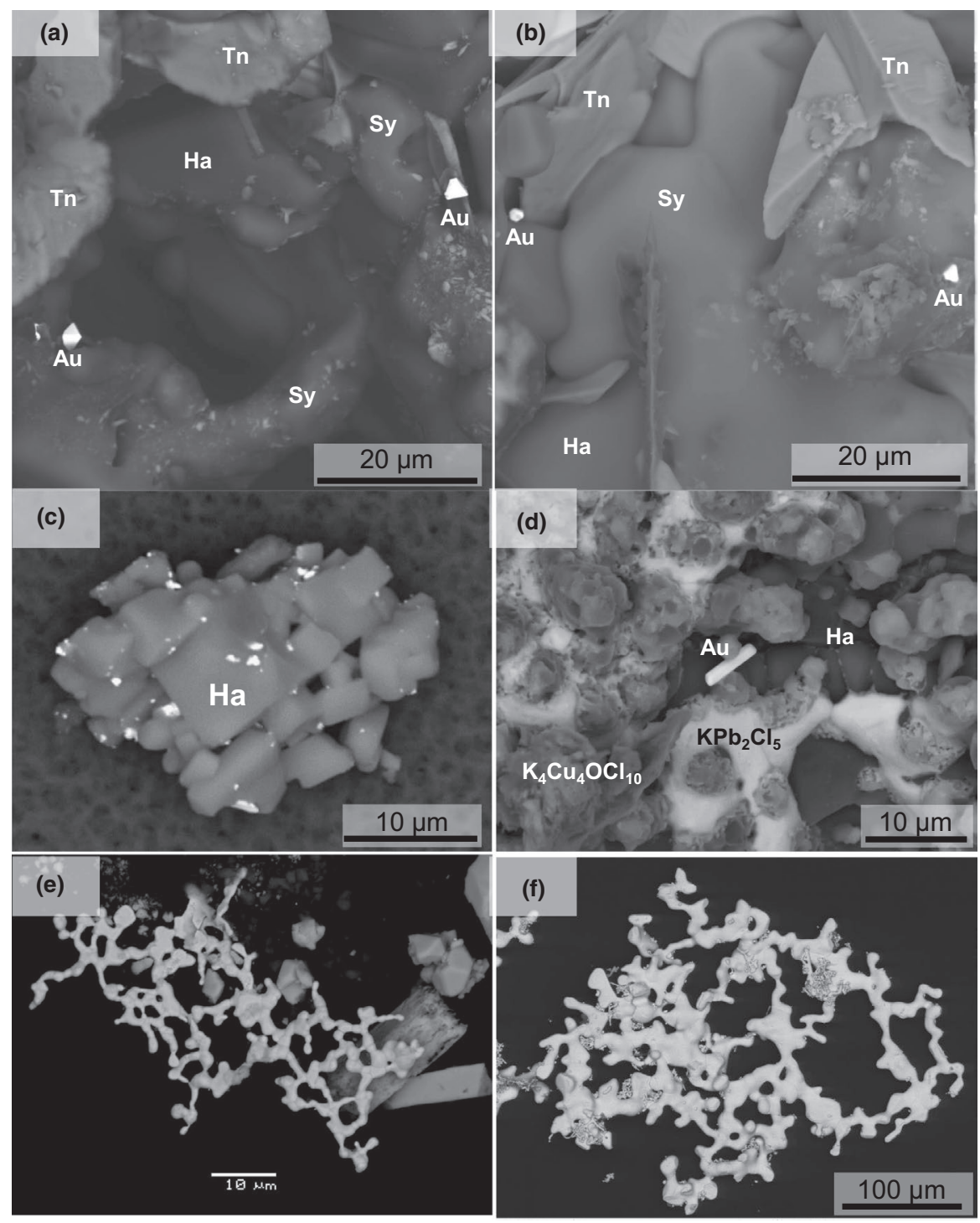

FIGURE 3 Backscattered electron images of native gold associated with chlorides in this study ( $a$ and $b$ representing boxed areas (a) and (b) respectively, on Figure 2e) and other studies of the Tolbachik eruption 2012-2013 (c,d after Zelenski et al., 2016 and e after Chaplygin et al., 2015) and experimental gold crystallized in salt melt (f; Shmulovich et al., 2018). Aerosol particle of $\mathrm{NaCl}$ crystals sprinkled with gold (c) was collected from the eruptive gases over the lava pond; individual crystals and aggregates of gold among fumarolic minerals, chlorides (d) and sulphates (e) on a lava surface 
$\mathrm{Cu}-\mathrm{Mg}$ spinel species together with hematite and orthopyroxene were found in the ignited $\mathrm{Cu}-\mathrm{Zn}$ ore dump in Newfoundland, where high-temperature roasting was caused by "the intense oxidation to which the ore dump was subjected during smouldering periods that roasted the sulphides" (Nickel, 1973). The high-Ca silicate mineral assemblage (Figure 2f; Figure S6, S7), especially esseneite, melilite, wollastonite, and garnet together with Fe-oxides and spinel (Cosca \& Peacor, 1987; Ganino, Libourel, \& Bernard, 2019), is also suggestive of pyrometamorphic transformations at the surface of solid lava, caused by hot gases. We imply that such "chemical" roasting at low pressure and high oxygen fugacity was caused by periodic bursts of high-temperature gas through the lava tubes. High, nearly magmatic temperature of the gaseous media in this case was independently confirmed by direct measurements of venting gases in skylights and lava fractures (Chaplygin et al., 2016; Zelenski et al., 2014; Figure S3) and magma dripping from the tube roof (Figure S4).

We further envisage that at near-magmatic temperatures the fumarolic chloride-sulphate mineral assemblage on the walls of lava tubes experienced de-volatilization and melting that may result in formation of tenorite and $\mathrm{Na}-\mathrm{K}$ chloride liquid respectively (Figure 2). As the salt liquid in the system $\mathrm{NaCl}-\mathrm{KCl}$ is stable the eutectic temperature of $657^{\circ} \mathrm{C}$, it can be both a flux and leaching agent, while covering, percolating through and interacting with the basaltic wallrock. Similar to natural samples in our study, the Tolbachik basalt scoria experimentally treated by $0.5 \mathrm{~mol} \% \mathrm{HCl}$ in air at $600^{\circ} \mathrm{C}$ developed a coat of halite, tenorite and hematite (Figure S8; Zelenski \& Taran, 2012).

Furthermore, exceptionally high solubility of gold in anhydrous chloride melt at oxidized conditions at high temperature $\left(\sim 850^{\circ} \mathrm{C}\right)$ in the presence of silica has been recorded in natural quartzhosted inclusions ( 10 ppm Au, Biely Vrch porphyry gold deposit, Koděra, Heinrich, Wälle, \& Lexa, 2014) and laboratory experiments (Shmulovich, Bukhtiyarov, \& Persikov, 2018). Importantly, octahedral crystals (Figure $3 a, b$ ) and mesh-like aggregates of gold (Figure $3 e$ ) in chlorides from the Tolbachik lava tubes are indistinguishable from the experimental gold formed upon crystallization of molten salt (Figure 3f; Shmulovich et al., 2018).

The discovery of native gold in association with $\mathrm{Na}-\mathrm{K}, \mathrm{K}-\mathrm{Cu}$ and $\mathrm{Cu}$ chlorides and oxychlorides in this (Figures 2e and 3a,b) and other studies (Figure 3c-e) of the Tolbachik lava tubes, skylights and cinder cones (e.g. Chaplygin et al., 2015; Vergasova et al., 2001; Zelenski et al., 2016) entails certain genetic constraints. Apparently, extraction of gold from magmas and rocks is most efficient in high-temperature chlorine-rich environments (e.g. alkali chloride melts), especially, in the presence of oxygen from air:

$$
2 \mathrm{NaCl}(\mathrm{m})+\mathrm{Au}(\mathrm{s})+1.5 \mathrm{O}_{2}(\mathrm{~g})+\mathrm{SiO}_{2}(\mathrm{~s})=\mathrm{AuCl}(\mathrm{m})+\mathrm{Na}_{2} \mathrm{SiO}_{3}(\mathrm{~s})
$$

where (m), (s) and (g) indicate liquid (melt), solid and gaseous phases.

In the case of Tolbachik basalts with average gold content of $3 \mathrm{ppb}$ (Zelenski et al., 2016), the extraction of $0.84 \mu \mathrm{g}$ of gold can occur from $1 \mathrm{~m}^{2}$ of the rock surface, which is affected by a hot salt flux to a depth of $100 \mu \mathrm{m}\left(10^{4} \mathrm{~cm}^{2} \times 10^{-2} \mathrm{~cm} \times 2.8 \mathrm{~g} / \mathrm{cm}^{3}=280 \mathrm{~g}\right)$. This potentially extracted amount of gold would be sufficient to form 1,360 gold crystals, like the one on Figure $3 \mathrm{~d}$ or 14,500 smaller grains like those on Figure $3 a, b$. The amount of extracted gold is smaller, if the extraction is incomplete, but larger by at least a factor of two, if the vesicular surface of the source basalt and metal diffusion from inner layers towards the surface are taken into account. Gold crystals are unlikely to have homogeneous distribution in the crystallized salt, but they are large enough to be discovered, even at low (optical) magnification.

In conclusion, our hypothesis envisages that in addition to metal transported by hydrothermal fluids gold accumulations in shallow volcanic environments are supplied by metals that are extracted from solid rocks by both hot $\mathrm{Cl}$-rich gases and salt melts. Near-magmatic temperature and efficiency of metal extraction in the post-eruptive environment are facilitated by elevated oxygen fugacity, which is caused by ingress of air into episodically emptied magmatic plumbing systems and consequent oxidation of fluids and metals. We further argue that metal buildups accompany and postdate every stage of magma injection and eruption. Metal accumulations scattered vertically and laterally in shallow magmatic conduits can be upgraded by coupled dissolution and re-deposition in successive volcanic cycles. It is also anticipated that long-lived volcanic systems, processing tens to hundreds of cubic $\mathrm{km}$ of magmas to the surface, are capable of attaining even higher gold endowments by scavenging precursor, fumarole-style accumulations of metals.

\section{ACKNOWLEDGEMENTS}

Maya Kamenetsky, Dmitry Savelyev, Kiril Shmulovich, Igor Pekov and Marina Belousova are thanked for good advice and sharing their expertise and data. Insightful comments by Yuri Taran, an anonymous reviewer and the editors of Terra Nova helped to improve the clarity of presentation and elaborate the conclusions. Field work and sample collection was partly supported by RFBR (16-05-00945a) and the State assignment project 0330-2016-0001. This study was funded by the Russian Science Foundation grant \#16-17-10145.

\section{DATA AVAILABILITY STATEMENT}

The authors confirm that the data supporting the findings of this study are available within the article and its supplementary materials, as well as from the corresponding author (VSK) upon request.

\section{ORCID}

Vadim S. Kamenetsky (iD https://orcid.org/0000-0002-2734-8790

\section{REFERENCES}

Belousov, A., \& Belousova, M. (2018). Dynamics and viscosity of 'a'a and pahoehoe lava flows of the 2012-2013 eruption of Tolbachik 
volcano, Kamchatka (Russia). Bulletin of Volcanology, 80, 6. https:// doi.org/10.1007/s00445-017-1180-2

Belousov, A., Belousova, M., Edwards, B., Volynets, A., \& Melnikov, D. (2015). Overview of the precursors and dynamics of the 2012-13 basaltic fissure eruption of Tolbachik Volcano, Kamchatka, Russia. Journal of Volcanology and Geothermal Research, 307, 22-37. https:// doi.org/10.1016/j.jvolgeores.2015.06.013

Burnham, C. W. (1998). Magmas and hydrothermal fluids. In H. L. Barnes (Ed.), Geochemistry of hydrothermal ore deposits (pp. 71-136). New York, NY: John Wiley \& Sons.

Chaplygin, I. V., Lavrushin, V. Y., Dubinina, E. O., Bychkova, Y. V., Inguaggiato, S., \& Yudovskaya, M. A. (2016). Geochemistry of volcanic gas at the 2012-13 New Tolbachik eruption, Kamchatka. Journal of Volcanology and Geothermal Research, 323, 186-193. https://doi. org/10.1016/j.jvolgeores.2016.04.005

Chaplygin, I., Yudovskaya, M., Vergasova, L., \& Mokhov, A. (2015). Native gold from volcanic gases at Tolbachik 1975-76 and 201213 fissure eruptions, Kamchatka. Journal of Volcanology and Geothermal Research, 307, 200-209. https://doi.org/10.1016/j.jvolg eores.2015.08.018

Cline, J. S., \& Bodnar, R. J. (1991). Can economic porphyry copper mineralization be generated by a typical calc-alkaline melt? Journal of Geophysical Research, 96, 8113-8126. https://doi.org/10.1029/91JB0 0053

Cooke, D. R., Hollings, P., \& Walshe, J. L. (2005). Giant porphyry deposits: Characteristics, distribution, and tectonic controls. Economic Geology, 100, 801-818. https://doi.org/10.2113/gsecongeo.100.5.801

Cooke, D. R., \& Simmons, S. F. (2000). Characteristics and genesis of epithermal gold deposits. In S. G. Hagemann, \& P. E. Brown (Eds.), Reviews in economic geology (pp. 221-244). New Haven, CT: Society of Economic Geologists.

Cosca, M. A., \& Peacor, D. R. (1987). Chemistry and structure of esseneite $\left(\mathrm{CaFe}^{3+} \mathrm{AlSiO}_{6}\right)$, a new pyroxene produced by pyrometamorphism. American Mineralogist, 72, 148-156.

Fulignati, P., \& Sbrana, A. (1998). Presence of native gold and tellurium in the active high-sulfidation hydrothermal system of the La Fossa volcano (Vulcano, Italy). Journal of Volcanology and Geothermal Research, 86, 187-198. https://doi.org/10.1016/ S0377-0273(98)00078-X

Ganino, C., Libourel, G., \& Bernard, A. (2019). Fumarolic incrustations at Kudryavy volcano (Kamchatka) as a guideline for high-temperature $\left(>850^{\circ} \mathrm{C}\right)$ extinct hydrothermal systems. Journal of Volcanology and Geothermal Research, 376, 75-85. https://doi.org/10.1016/j.jvolg eores.2019.03.020

Hannington, M., Hardardóttir, V., Garbe-Schönberg, D., \& Brown, K. L. (2016). Gold enrichment in active geothermal systems by accumulating colloidal suspensions. Nature Geoscience, 9, 299-302. https://doi. org/10.1038/ngeo2661

Hedenquist, J. W., \& Lowenstern, J. B. (1994). The role of magmas in the formation of hydrothermal ore deposits. Nature, 370, 519-527. https:// doi.org/10.1038/370519a0

Henley, R. W., \& Berger, B. R. (2013). Nature's refineries - Metals and metalloids in arc volcanoes. Earth-Science Reviews, 125, 146-170. https://doi.org/10.1016/j.earscirev.2013.07.007

Herrington, R. J., \& Wilkinson, J. J. (1993). Colloidal gold and silica in mesothermal vein systems. Geology, 21, 539-542. https://doi. org/10.1130/0091-7613(1993)021<0539:CGASIM>2.3.CO

Hurtig, N. C., \& Williams-Jones, A. E. (2015). Porphyry-epithermal AuAg-Mo ore formation by vapor-like fluids: New insights from geochemical modeling. Geology, 43, 587-590. https://doi.org/10.1130/ G36685.1

Koděra, P., Heinrich, C. A., Wälle, M., \& Lexa, J. (2014). Magmatic salt melt and vapor: Extreme fluids forming porphyry gold deposits in shallow subvolcanic settings. Geology, 42, 495-498. https://doi. org/10.1130/G35270.1
Meeker, K. A., Chuan, R. L., Kyle, P. R., \& Palais, J. M. (1991). Emission of elemental gold particles from Mount Erebus, Ross Island, Antarctica. Geophysical Research Letters, 18, 1405-1408. https://doi. org/10.1029/91GL01928

Nickel, E. H. (1973). The new mineral cuprospinel $\left(\mathrm{CuFe}_{2} \mathrm{O}_{4}\right)$ and other spinels from an oxidized ore dump at Baie Verte, Newfoundland. The Canadian Mineralogist, 11, 1003-1007.

Pekov, I., Sandalov, F., Koshlyakova, N., Vigasina, M., Polekhovsky, Y., Britvin, S., ... Turchkova, A. (2018). Copper in natural oxide spinels: The new mineral thermaerogenite $\mathrm{CuAl}_{2} \mathrm{O}_{4}$, cuprospinel and $\mathrm{Cu}$-enriched varieties of other spinel-group members from fumaroles of the Tolbachik volcano, Kamchatka, Russia. Minerals, 8, 498. https:// doi.org/10.3390/min8110498

Saunders, J. A. (1990). Colloidal transport of gold and silica in epithermal precious-metal systems: Evidence from the Sleeper deposit, Nevada. Geology, 18, 757-760. https://doi. org/10.1130/0091-7613(1990)018<0757:CTOGAS>2.3.CO;2

Saunders, J. A. (1994). Silica and gold textures in bonanza ores of the sleeper deposit, Humboldt County, Nevada: Evidence for colloids and implications for epithermal ore-forming processes. Economic Geology, 89, 628-638. https://doi.org/10.2113/gsecongeo.89.3.628

Saunders, J. A., \& Schoenly, P. A. (1995). Boiling, colloid nucleation and aggregation, and the genesis of bonanza $\mathrm{Au}-\mathrm{Ag}$ ores of the sleeper deposit. Nevada Mineralium Deposita, 30, 199-210. https://doi. org/10.1007/BF00196356

Schlesinger, M. E., King, M. J., Sole, K. C., \& Davenport, W. G. (2011). Extractive metallurgy of copper (5th ed.). Oxford, UK: Elsevier. 455 p.

Serafimova, E. K., Kazmin, L. A., \& Dobroskok, T. A. (2001). Gold geochemistry in posteruptive activity on cinder cones produced on the Northern fissure of the Great Tolbachik flank eruption in 1975-1976. Volcanology and Seismology, 22, 397-416.

Sharygin, V., Kamenetsky, V., Zhitova, L., Belousov, A., \& Abersteiner, A. (2018). Copper-containing magnesioferrite in vesicular trachyandesite in a lava tube from the 2012-2013 eruption of the Tolbachik Volcano, Kamchatka. Russia Minerals, 8, 514. https://doi. org/10.3390/min8110514

Shmulovich, K. I., Bukhtiyarov, P. G., \& Persikov, E. S. (2018). Gold dissolution in dry salt melts in the presence of $\mathrm{SiO}_{2}$ as a function of $\left.\mathrm{P}_{2} \mathrm{O}_{2}\right)$. Geochemistry International, 56, 240-245. https://doi.org/10.1134/ S0016702918030084

Sillitoe, R. H. (1993). Giant and bonanza gold deposits in the epithermal environment: Assessment of potential genetic factors. In B. $\mathrm{H}$. Whiting, C. J. Hodgson, \& R. Mason (Eds.), Giant ore deposits. New Haven, CT: Society of Economic Geologists.

Sillitoe, R. H. (2010). Porphyry copper systems. Economic Geology, 105, 3-41. https://doi.org/10.2113/gsecongeo.105.1.3

Taran, Y. A., Bernard, A., Gavilanes, J. C., \& Africano, F. (2000). Native gold in mineral precipitates from high-temperature volcanic gases of Colima volcano. Mexico Applied Geochemistry, 15, 337-346. https:// doi.org/10.1016/S0883-2927(99)00052-9

Taylor, B. E. (2007). Epithermal gold deposits. In W. D. Goodfellow (Ed.), Mineral deposits of Canada: A synthesis of major deposit-types, district metallogeny, the evolution of geological provinces, and exploration methods. Geological Association of Canada.

Vergasova, L. P., \& Filatov, S. K. (2012). New mineral species in products of fumarole activity of the Great Tolbachik fissure eruption. Journal of Volcanology and Seismology, 6, 281-289. https://doi.org/10.1134/ S0742046312050053

Vergasova, L. P., Starova, G. L., Serafimova, E. K., Filatov, S. K., Filosofova, T. M., \& Dunin-Barkovskii, R. L. (2001). Native gold deposits from gas emanations of cinder cones produced by the 1975-1976 Great Tolbachik fissure eruptions. Volcanology and Seismology, 22, 493-504.

Williams-Jones, A. E., Bowell, R. J., \& Migdisov, A. A. (2009). Gold in solution. Elements, 5, 281-287. https://doi.org/10.2113/gsele ments.5.5.281 
Williams-Jones, A. E., \& Heinrich, C. A. (2005). Vapor transport of metals and the formation of magmatic-hydrothermal ore deposits. Economic Geology, 100, 1287-1312.

Yudovskaya, M. A., Distler, V. V., Chaplygin, I. V., Mokhov, A. V., Trubkin, N. V., \& Gorbacheva, S. A. (2006). Gaseous transport and deposition of gold in magmatic fluid: Evidence from the active Kudryavy volcano, Kurile Islands. Mineralium Deposita, 40, 828-848. https://doi. org/10.1007/s00126-005-0034-6

Zelenski, M., Kamenetsky, V. S., \& Hedenquist, J. (2016). Gold recycling and enrichment beneath volcanoes: A case study of Tolbachik, Kamchatka. Earth and Planetary Science Letters, 437, 35-46. https:// doi.org/10.1016/j.epsl.2015.12.034

Zelenski, M., Malik, N., \& Taran, Y. (2014). Emissions of trace elements during the 2012-2013 effusive eruption of Tolbachik volcano, Kamchatka: Enrichment factors, partition coefficients and aerosol contribution. Journal of Volcanology and Geothermal Research, 285, 136-149. https://doi.org/10.1016/j.jvolgeores.2014.08.007

Zelenski, M., \& Taran, Y. (2012). Volcanic emissions of molecular chlorine. Geochimica Et Cosmochimica Acta, 87, 210-226. https://doi. org/10.1016/j.gca.2012.03.034

\section{SUPPORTING INFORMATION}

Additional supporting information may be found online in the Supporting Information section at the end of the article.

Data S1. Analytical methods.

How to cite this article: Kamenetsky VS, Belousov A, Sharygin $V V$, et al. High-temperature gold-copper extraction with chloride flux in lava tubes of Tolbachik volcano (Kamchatka). Terra Nova. 2019;31:511-517. https://doi.org/10.1111/ ter.12420 


\section{Supplementary Information (Analytical Methods)}

Double-polished rock sections ( $\sim 50 \mu \mathrm{m}$ in thickness) and polished rock fragments mounted in epoxy resin were used for transmitted and reflected light microscope examination of the Duplex basaltic trachyandesite rock with chloride coatings (Figure 2a). During the preparation of polished samples, no water-bearing abrasives were used. Identification of minerals was based on energy-dispersive spectra (EDS), back-scattered electron (BSE) images and elemental mapping (EDS system), using a TESCAN MIRA 3MLU scanning electron microscope equipped with an INCA Energy 450 XMax 80 microanalysis system (Oxford Instruments Ltd.) at the V.S. Sobolev Institute of Geology and Mineralogy (IGM), Novosibirsk, Russia and a Hitachi SU-70 Schottky field emission scanning electron microscope fitted with Oxford INCA Energy XMax 80 silicon drift detector energy dispersive system at Central Science Laboratory, University of Tasmania, Hobart, Australia. The instruments were operated at an accelerating voltage of $15-20 \mathrm{kV}$ and a probe current of $1 \mathrm{nA}$ in high-vacuum modes, and accumulation time of $20 \mathrm{~s}$. The following simple compounds and metals were used as reference standards for most of the elements: $\mathrm{SiO}_{2}(\mathrm{Si}$ and $\mathrm{O}), \mathrm{Al}_{2} \mathrm{O}_{3}(\mathrm{Al})$, diopside $(\mathrm{Mg}$ and $\mathrm{Ca}$ ), albite (Na), orthoclase (K), $\mathrm{Ca}_{2} \mathrm{P}_{2} \mathrm{O}_{7}(\mathrm{P}), \mathrm{BaF}_{2}(\mathrm{Ba}$ and $\mathrm{F}), \mathrm{Cr}_{2} \mathrm{O}_{3}(\mathrm{Cr}), \mathrm{CsRe}_{2} \mathrm{Cl}_{6}(\mathrm{Cl}), \mathrm{LaPO}_{4}$ (La), $\mathrm{CePO}_{4}(\mathrm{Ce}), \mathrm{SrF}_{2}(\mathrm{Sr})$, metallic Ti, $\mathrm{Fe}, \mathrm{Mn}, \mathrm{Zn}, \mathrm{Ni}, \mathrm{V}$ and $\mathrm{Cu}$. Correction for matrix effects was done using the XPP algorithm, implemented in the software of the microanalysis system. Metallic Co served for quantitative optimization (normalization to probe current and energy calibration of the spectrometer).

Electron microprobe analyses (EMPA) in wavelength-dispersive (WDS) mode were performed for rock-forming and opaque minerals from the Tolbachik rocks using a JXA-8100 microprobe (Jeol Ltd) at IGM. Grains previously analyzed by EDS were selected for this purpose. The operating conditions were as follows: beam diameter of 1-2 $\mu \mathrm{m}$, accelerating voltage of $20 \mathrm{kV}$, beam current of $30 \mathrm{nA}$, and counting time of $10(5+5) \mathrm{s}$. The following standards were used for opaque and related minerals: $\mathrm{MgFe}_{2} \mathrm{O}_{4}\left(\mathrm{Fe}\right.$ and $\mathrm{Mg}$ ), $\mathrm{MnFe}_{2} \mathrm{O}_{4}(\mathrm{Mn}), \mathrm{MgAl}_{2} \mathrm{O}_{4}(\mathrm{Al}), \mathrm{ZnFe}_{2} \mathrm{O}_{4}(\mathrm{Zn})$, rutile (Ti), $\mathrm{NiFe}_{2} \mathrm{O}_{4}(\mathrm{Ni}), \mathrm{V}_{2} \mathrm{O}_{5}(\mathrm{~V}), \mathrm{Cr}_{2} \mathrm{O}_{3}(\mathrm{Cr})$, diopside $(\mathrm{Ca}$ and $\mathrm{Si})$, albite $(\mathrm{Na})$, orthoclase $(\mathrm{K})$, and fluorapatite (P). Correction for matrix effects was done using a PAP routine. The precision of analysis for major elements was better than $2 \%$ relative. The detection limits for elements are (in ppm): $\mathrm{Si}-196 ; \mathrm{Ti}-$ $150 ; \mathrm{Cr}-248 ; \mathrm{V}-141 ; \mathrm{Al}-255 ; \mathrm{Fe}-146 ; \mathrm{Mn}-122 ; \mathrm{Mg}-168 ; \mathrm{Ca}-105 ; \mathrm{Na}-337 ; \mathrm{K}-85 ; \mathrm{Zn}-$ 266; $\mathrm{Cu}-226 ; \mathrm{P}-259$.

Raman spectroscopy was used to characterize $\mathrm{Cu}$-rich-magnesioferrite in the Tolbachik rock. We used a LabRAM HR $800 \mathrm{~mm}$ (HORIBA Scientific Ltd.) spectrometer equipped with a CCD detector and coupled to an Olympus BX40 confocal microscope (objective x100) at IGM. A semiconductor laser emitting at $514.5 \mathrm{~nm}$ with a nominal power output of $50 \mathrm{~mW}$ was used for excitation. In each case, 20 spectra were recorded for $20 \mathrm{~s}$ each at a hole diameter of $100 \mu \mathrm{m}$ and integrated. The spectra were recorded between 100 and $1200 \mathrm{~cm}^{-1}$, and the monochromator was calibrated using the $520.7 \mathrm{~cm}^{-1}$ Raman line of elemental Si. 


\section{Supplementary Information (Figures)}

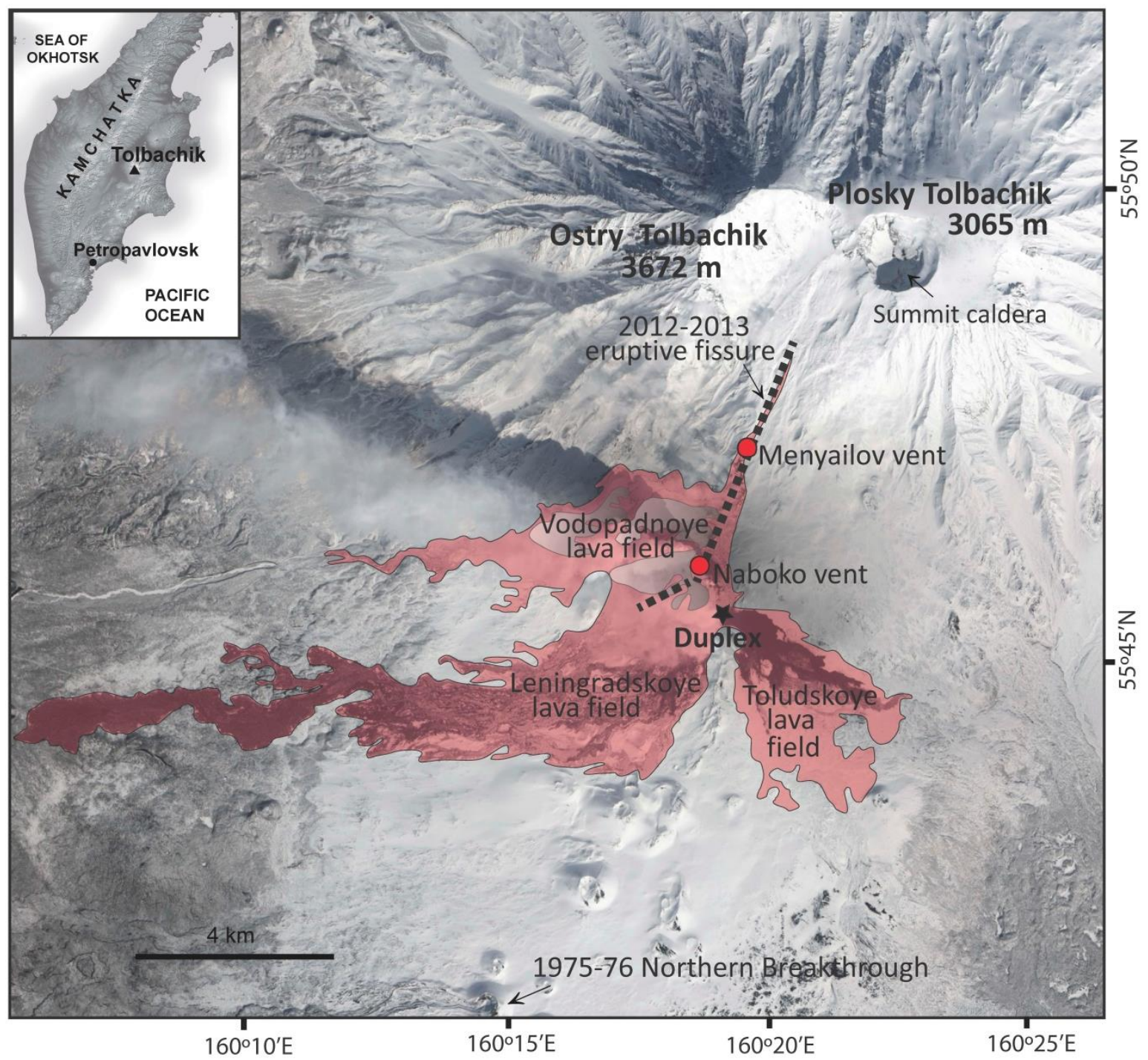

Figure S-1. Sketch map (with modifications after Belousov et al., 2015) showing the distribution of the 2012-2013 Tolbachik eruption lava fields superimposed over a NASA EO-1ALI satellite image taken on 5 April 2013. Lava fields (red areas), eruptive fissures (dashed line), main vents (red dots) and the location of the "Duplex" lava tube segment/sampling site (asterisk). The inset shows the location of the Tolbachik Volcano on the Kamchatka Peninsula. EO-1 image is courtesy of NASA's Earth Observing One (EO-1) satellite managed by the GoddardSpace Flight Center (http://eo1.gsfc.nasa.gov). 

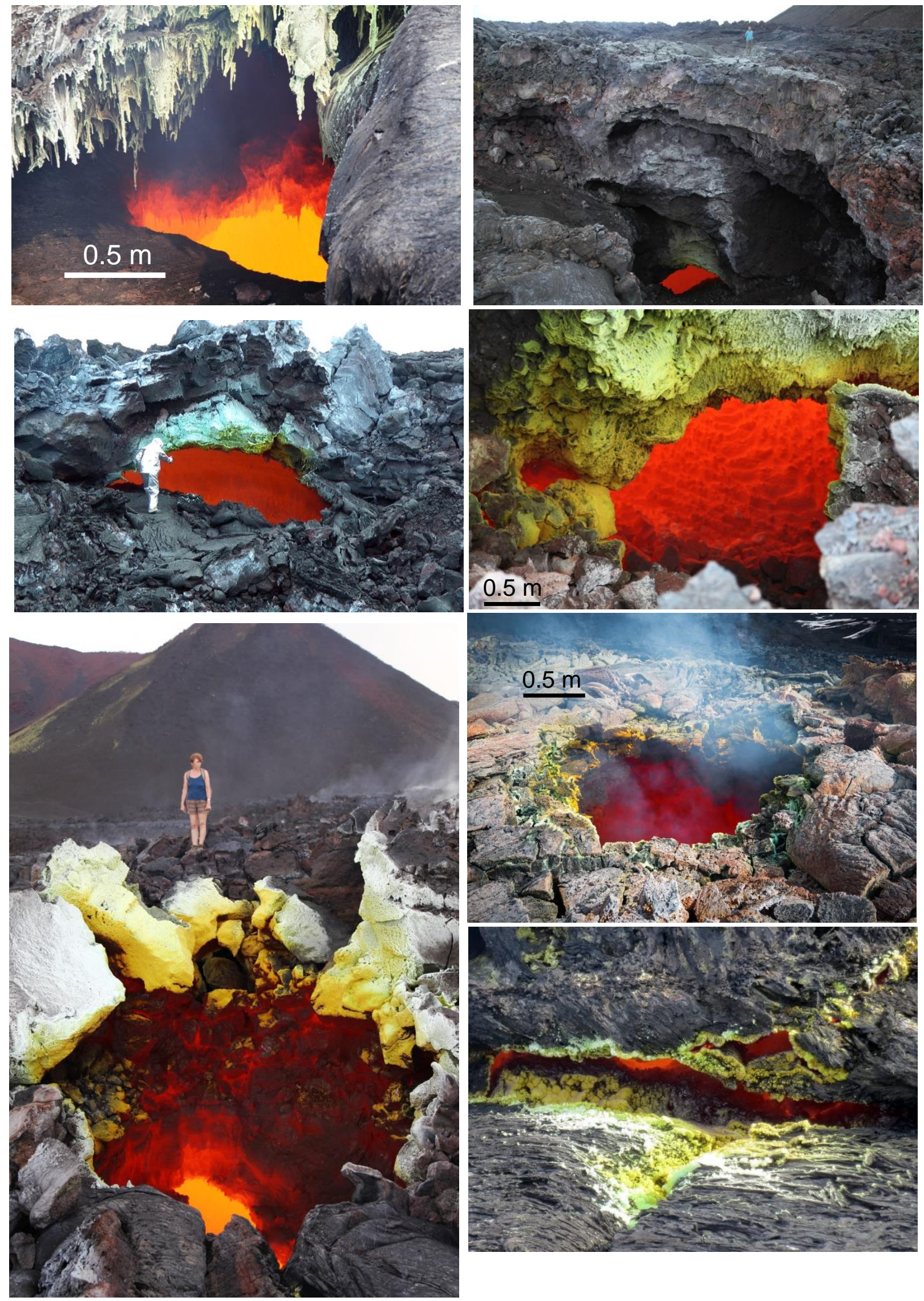

Figure S-2. Glowing skylights and fractures in roofs of the lava tubes, 2012-13 Tolbachik eruption. Colorful incrustations around skylights and fractures, deposited directly from the cooling gas - air mixtures (temperature $>900^{\circ} \mathrm{C}$ ) are dominated by $\mathrm{Cu}-\mathrm{Na}-\mathrm{K}$ chlorides and sulfates. Photos by $\mathrm{A}$. Belousov and I. Chaplygin. 


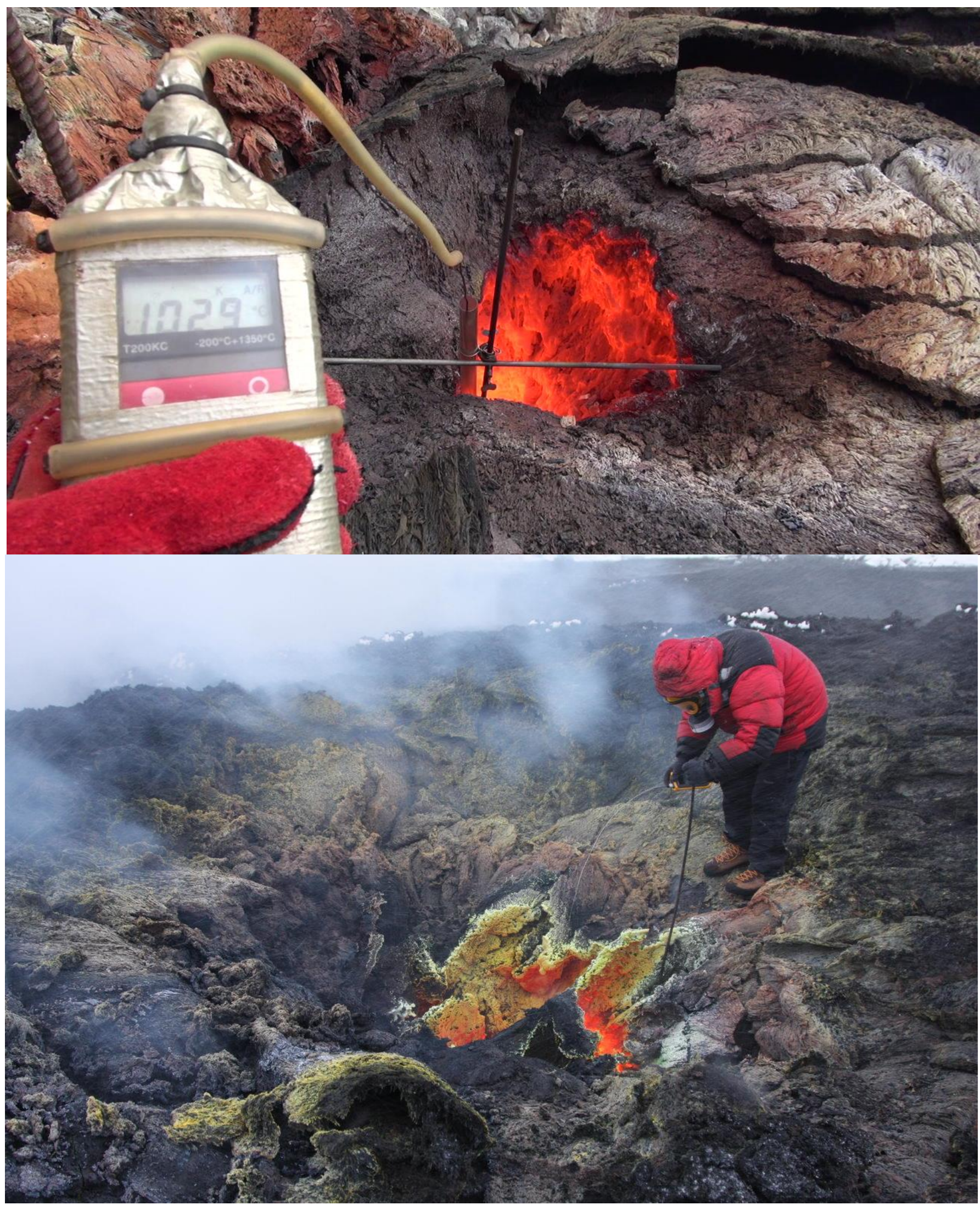

Figure S-3. Volcanologists Ilya Chaplygin and Michael Zelenski perform measurements of temperature and composition of gas - air mixtures emitted in the roofs of lava tubes through skylights and fractures. Photos by M. Yudovskaya. 


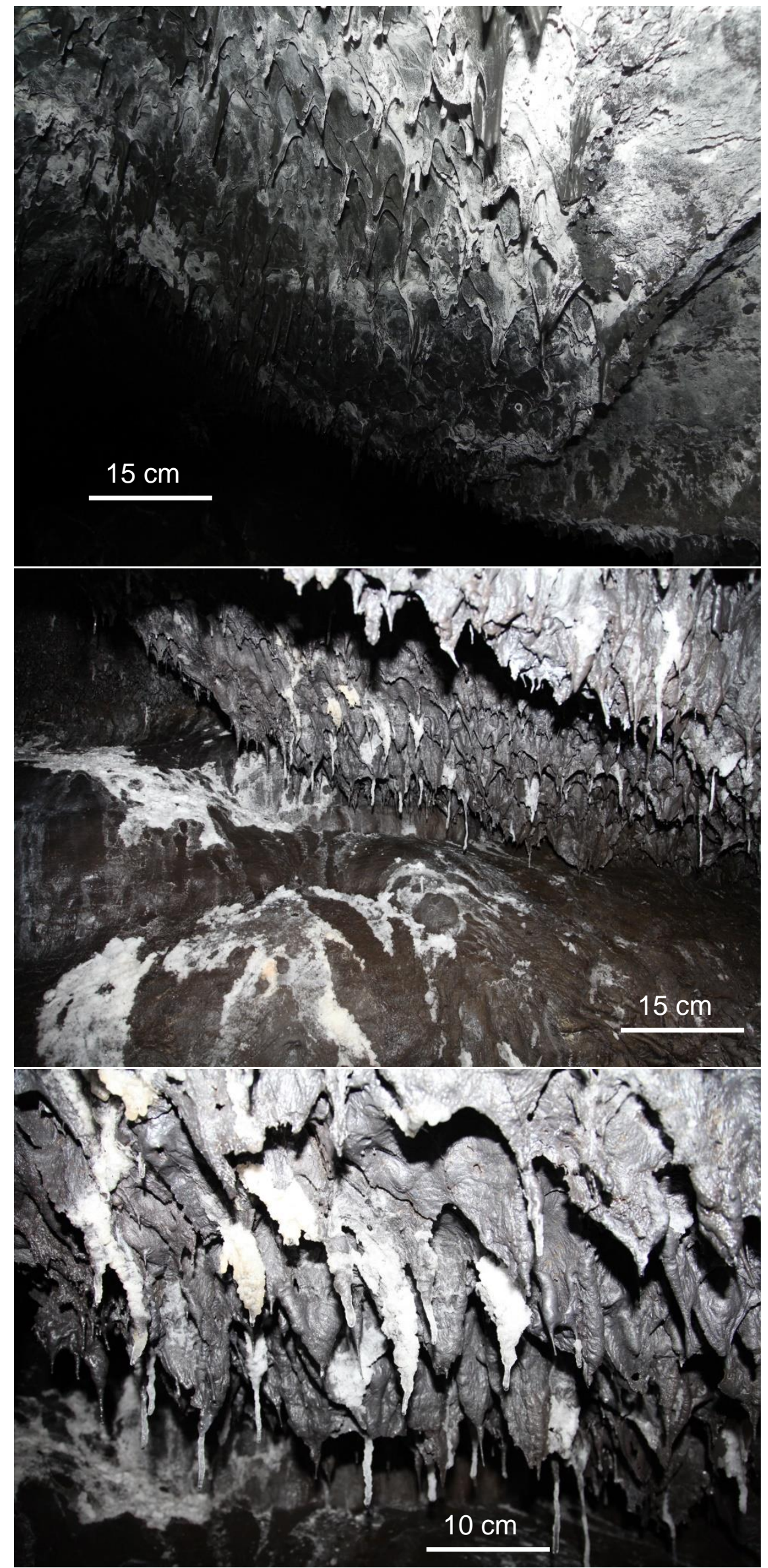

Figure S-4. Lava "stalaktites' covered with chlorides on the roof of the "Duplex" cave/lava tube segment in June 2018. Photos by A. Belousov. 

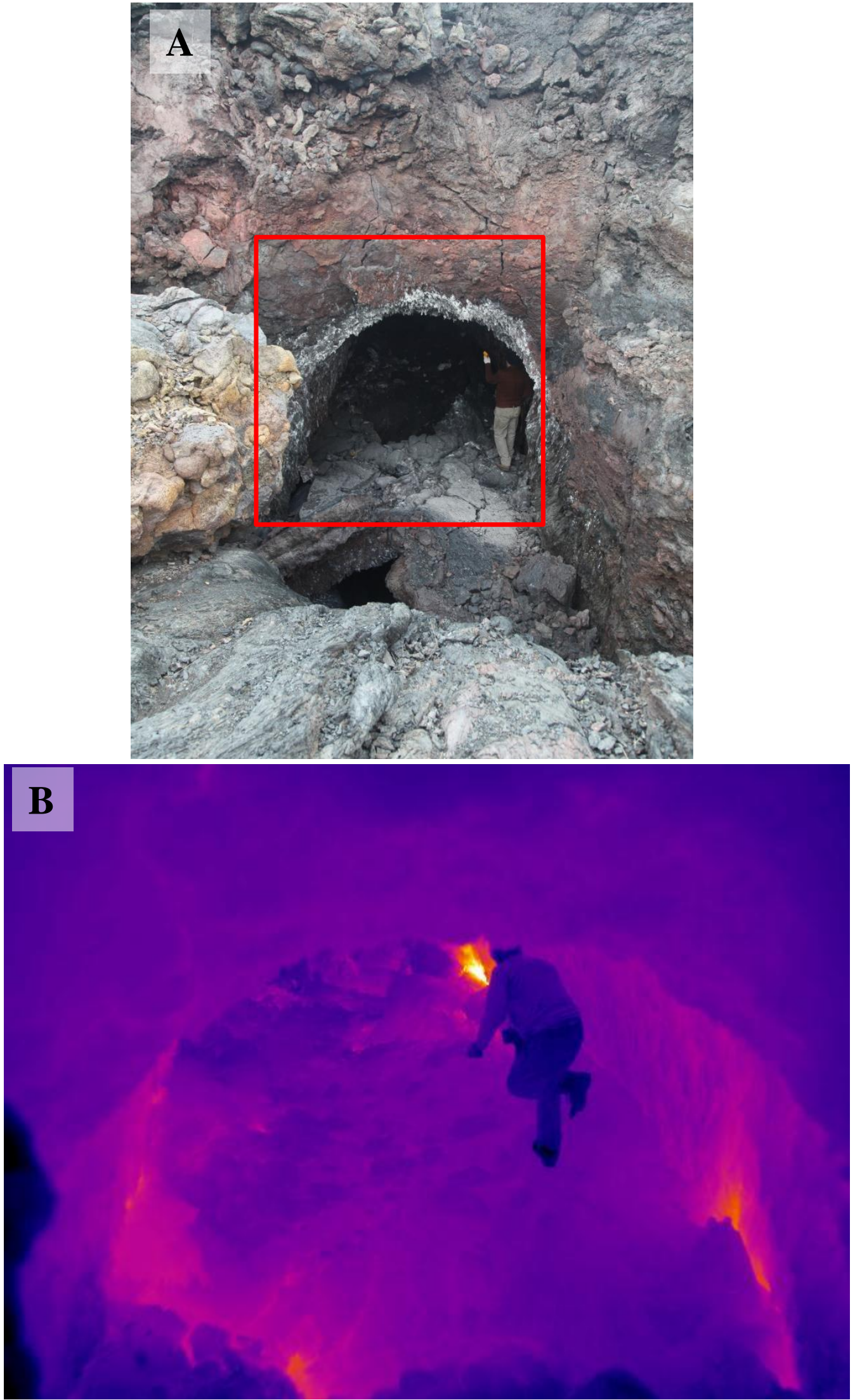

Figure S-5. Entrance into the "Duplex" lava tube of the 2012-2013 eruption of the Tolbachik volcano; June 2017. A. Conventional photograph by A. Belousov; B. FLIR image of the area indicated by the rectangle in A., courtesy of S.A. Chirkov. Temperatures of the tube walls and inside the wall fracture are $\sim 60^{\circ} \mathrm{C}$ and $>200^{\circ} \mathrm{C}$, respectively. 


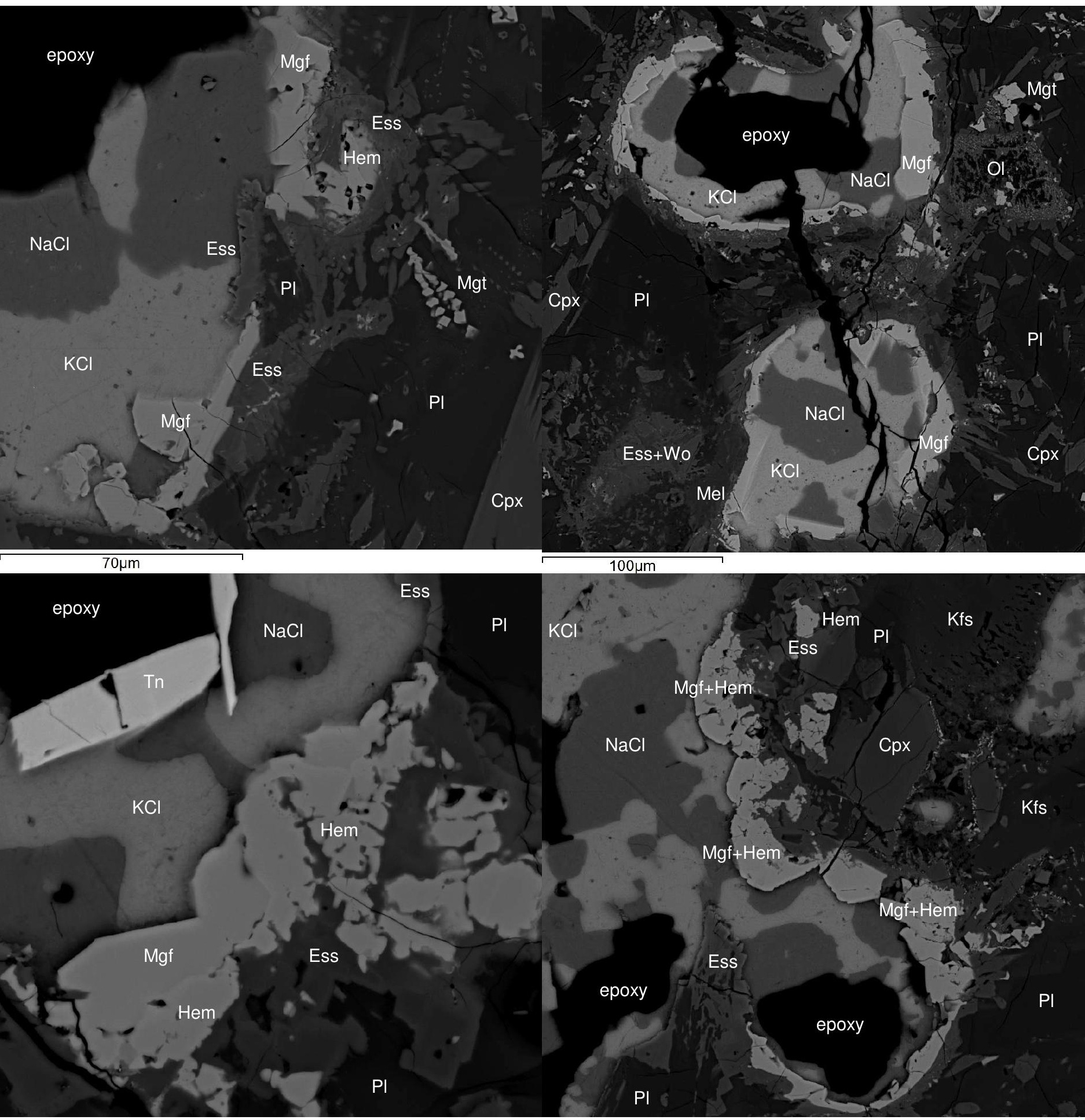

$20 \mu \mathrm{m}$

$80 \mu \mathrm{m}$

Figure S-6. Mineral assemblages at the contact of salty crusts covering basalt walls of the "Duplex" lava tube segment.

Mgf - Cu-magnesioferrite; Tn - tenorite; $\mathrm{Hem}$ - Cu- or Ti-rich hematite; Mgt - Ti-rich magnetite; $\mathrm{Pl}$ Na-Ca-plagioclase; $\mathrm{Cpx}$ - subcalcium diopside; Ess - esseneite-rich clinopyroxene; Mel - Na-rich melilite; Ol - olivine; Kfs - K-feldspar; Wo -wollastonite; Mnt - monticellite; 


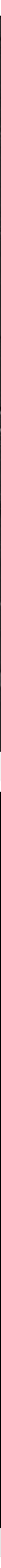

Figure S-7. Mineral assemblages at the contact of salty crusts covering basalt walls of the "Duplex" lava tube segment.

Mgf - Cu-magnesioferrite; $\mathrm{Tn}$ - tenorite; $\mathrm{Hem}$ - $\mathrm{Cu}$ - or Ti-rich hematite; Mgt - Ti-rich magnetite; $\mathrm{Pl}$ Na-Ca-plagioclase; Cpx - subcalcium diopside; Ess - esseneite-rich clinopyroxene; Mel - Na-rich melilite; Ol - olivine; Kfs - K-feldspar; Wo -wollastonite; Mnt - monticellite; 


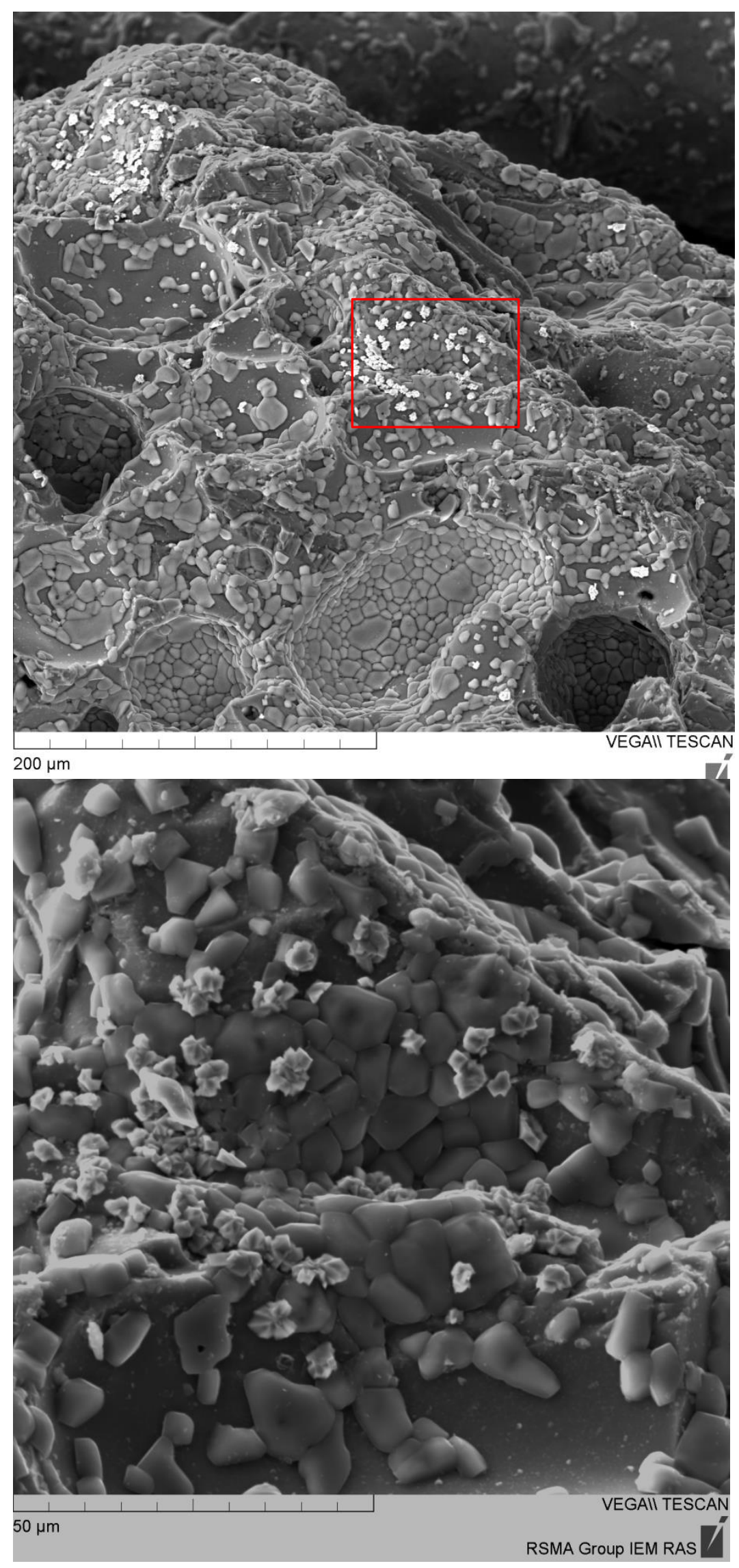

Figure S-8. Secondary electron images showing experimental products (halite, tenorite and hematite) of interaction between the Tolbachik basaltic scoria and $0.5 \mathrm{~mol} \% \mathrm{HCl}$ with air at $600 \mathrm{C}$ for $24 \mathrm{~h}$ (Zelenski and Taran, 2012). 